\title{
PEMODELAN TINGKAT RUMAH TANGGA KUMUH PERKOTAAN DI INDONESIA TAHUN 2019 MENGGUNAKAN BINOMIAL NEGATIF
}

Studi Kasus Susenas Maret 2019

\author{
Modeling The Level of Urban Slum Households in Indonesia 2019 Using Negative \\ Binomials \\ Case Study Susenas Maret 2019
}

Ary Vebryan ${ }^{1}$, Erni Tri Astuti ${ }^{2}$

Politeknik Statistika STIS ${ }^{1}$

Politeknik Statistika STIS ${ }^{2}$

Pondok Semanan Indah Blok B No. 3 (Tahoma 10 pt)

E-mail: 1 16.9027@stis.ac.id, ${ }^{2}$ Erni@stis.ac.id

\begin{abstract}
ABSTRAK
Menurut World Bank, pada tahun 2045 diproyeksikan 70 dari 100 orang akan tinggal di wilayah perkotaan di Indonesia. Bertambahnya jumlah penduduk di perkotaan akan menambah pula tuntutan kebutuhan dasar manusia, terutama perumahan. Permasalahan ini akan menimbulkan tumbuhnya rumah tangga kumuh di wilayah perkotaan karena adanya keterbatasan lahan. Pengetasan kawasan kumuh menjadi salah satu target dari Sustainable Development Goals 2015-2030 dan Rencana Pembangunan Jangka Panjang tahun 2005-2025. Penelitian ini bertujuan untuk mengetahui gambaran umum rumah tangga kumuh perkotaan di Indonesia, memodelkan tingkat rumah tangga kumuh perkotaan di Indonesia dengan model regresi untuk data count, mengidentifikasi faktor-faktor yang berpengaruh terhadap tingkat rumah tangga kumuh perkotaan. Pemodelan sederhana terhadap tingkat rumah tangga kumuh yang tinggal di perkotaan menggunakan Regresi Poisson. Namun, seringkali data observasi terjadi masalah overdispersi atau nilai varians melebihi nilai meannya. Salah satu cara alternatif untuk mengatasi masalah overdispersi dengan menggunakan Regresi Binomial Negatif. Hasil penelitian menunjukkan bahwa tingkat pengganguran terbuka, persentase rumah tangga miskin, persentase hunian bukan milik sendiri, dan tipologi wilayah merupakan variabel bebas yang berpengaruh positif dan signifikan terhadap tingkat rumah tangga kumuh perkotaan. Pengetahuan tentang variabel yang berpengaruh diharapkan dapat membantu pengetasan kawasan kumuh agar kesejahteraan masyarakat perkotaan dapat meningkat.
\end{abstract}

Kata kunci: tingkat rumah tangga kumuh perkotaan, overdispersi, Regresi Poisson, Regresi Binomial Negatif

\begin{abstract}
According to the World Bank, it is projected that 70 out of 100 people will live in urban areas in Indonesia by 2045. Increasing the population in urban areas will also increase the demands for basic human needs, especially housing. This problem will lead to the growth of slum households in urban areas due to limited land. Slum hacking is one of the targets of the 2015-2030 Sustainable Development Goals and the 2005-2025 Long-Term Development Plan. This study aims to determine the general picture of urban slum households in Indonesia, model the level of urban slum households in Indonesia with a regression model for the data count, identify the factors that affect the level of urban slum households. Simple modeling of the level of slum households living in urban areas using Poisson Regression. However, it is often observed that there are overdispersion problems or the variance exceeds the mean value. One alternative way to solve the overdispersion problem is using Negative Binomial Regression. The results showed that the level of open unemployment, the percentage of poor households, the percentage of non-owned dwellings, and the typology of the area were independent variables that had a positive and significant effect on the level of urban slum households. Knowledge of influential variables is expected to help reduce s/um areas so that the welfare of urban communities can increase.
\end{abstract}

Keywords: the level of urban slum households, overdispersion, Poisson Regression, Negative Binomial Regression 


\section{PENDAHULUAN}

Menurut World Bank, pada tahun 2045 diproyeksikan 70 dari 100 orang akan tinggal di wilayah perkotaan di Indonesia. Bertambahnya jumlah penduduk di perkotaan akan menambah kebutuhan pokok manusia, perumahan khusus. Permasalahan ini akan menimbulkan tumbuhnya rumah tangga kumuh di wilayah perkotaan karena ada keterbatasan lahan. Konsekuensi ekonomis yang diterima adalah harga lahan di perkotaan semakin tinggi, sehingga bagi penduduk perkotaan dengan penghasilan rendah akan sulit memiliki rumah sendiri (Rindarjono, 2017). Dampak yang terjadi adalah penduduk perkotaan terpaksa bermukim di tempat umum seperti bantaran sungai, di bawah jembatan dan di samping rel kereta api yang kemudian akan menjadikan daerah tersebut kumuh. Masalah klasik permukiman kumuh menjadi perhatian yang cukup serius bagi pemerintah. Permukiman kumuh adalah permukiman yang tidak layak huni karena ketidakteraturan bangunan, tingkat kepadatan bangunan yang tinggi, dan kualitas bangunan serta sarana dan prasarana yang tidak memenuhi syarat. Syarat-syarat yang dimaksud seperti pasokan air, drainase untuk kehidupan standar kurang memadai, kondisi yang tidak sehat tersebar luas dan mempercepat perkembangan penyakit (Tanni, Hasan, Azad, \& Bakali, 2014). Oleh karena itu, seseorang yang bermukim di permukiman kumuh lebih rentan terserang penyakit.

World Bank (2015) menyatakan bahwa Indonesia tengah mengalami perubahan bersejarah dan menjadikan ekonomi perkotaan sebagai pilar utama pembangunan. Pada periode tahun 2000 sampai 2010, luas lahan di daerah perkotaan Indonesia hanya meningkat secara rata-rata 1,1 persen per tahun. Sementara itu pertumbuhan populasi perkotaan adalah sebesar 3,5 persen per tahun. Hal ini mengakibatkan peningkatan total kepadatan penduduk perkotaan dari 7.400 jiwa/ $/ \mathrm{km}^{2}$ pada tahun 2000 menjadi $9.400 \mathrm{jiwa} / \mathrm{km}^{2}$ pada tahun 2010. Berdasarkan data tersebut diperkirakan permukiman kumuh di wilayah perkotaan akan menjadi masalah yang serius bagi Indonesia di masa depan.

Masalah klasik perkotaan tersebut masih menjadi perhatian khusus terutama bagi Perserikatan Bangsa-Bangsa (PBB). Oleh karena itu PBB menetapkan Sustainable Development Goals 2015-2030 nomor 11 yakni mewujudkan kota-kota dan permukiman yang inklusif, aman tangguh, dan berkelanjutan. Kemudian Pemerintah Indonesia mendukung kesepakatan tersebut dengan membuat Rencana Pembangunan Jangka Panjang (RPJP) tahun 2005-2025 dan Rencana Pembangunan Jangka Menengah Nasional (RPJMN) tahun 2020-2024, tercantum pada salah satu arah kebijakan yang berkaitan dengan perumahan dan permukiman, yakni terpenuhinya kebutuhan hunian yang dilengkapi sarana dan prasarana bagi seluruh masyarakat untuk mewujudkan kota tanpa permukiman kumuh.

UN Habitat (2006) menyatakan bahwa rumah tangga kumuh merupakan sekelompok individu yang hidup di bawah atap yang sama pada daerah perkotaan yang kurang memenuhi satu atau lima kondisi antara lain : ketahanan rumah, kecukupan tempat tinggal, akses air bersih, akses sanitasi yang memadai, dan kepemilikkan yang aman. Sedangkan BPS dalam mengukur rumah tangga kumuh hanya menggunakan empat indikator seperti air minum layak, sanitasi layak, sufficient living area, dan durability of housing.

Menurut Suparlan (2004), sebagian besar penghuni permukiman kumuh bertempat tinggal dibangunan yang padat dengan kondisi tidak memadai dan bekerja di sektor informal atau mempunyai mata pencarian tambahan dengan berpenghasilan rendah. Hal tersebut akan menurunkan kondisi hidup seseorang dan kualitas lingkungan setempat. Apabila daerah kumuh diabaikan keberadaannya maka akan berdampak pada menurunnya estetika perkotaan, serta akan menimbulkan permasalahan lainnya seperti bertambahnya aksi kriminalitas, kerawanan penyakit dan kerawanan kebakaran (Rindarjono,2017).

Penelitian mengenai kawasan kumuh melalui pendekatan rumah tangga kumuh perkotaan masih jarang dilakukan untuk seluruh wilayah perkotaan Indonesia. Sementara itu kajian komprehensif sangat diperlukan untuk mengwujudkan rencana strategis Kementerian Pekerjaan Umum Perumahan Rakyat (PUPR) tahun 2020-2024. Isi dari rencana strategis tersebut salah satunya adalah mengatasi kawasan kumuh perkotaan hingga 0 hektare pada tahun 2025 hingga 2030.

Dengan demikian, tujuan dari penelitian untuk mengetahui gambaran umum rumah tangga kumuh perkotaan di Indonesia, memodelkan tingkat rumah tangga kumuh perkotaan di Indonesia 1074 
dengan model regresi untuk data count dan mendapatkan faktor-faktor yang dapat memengaruhi tingkat rumah tangga kumuh.

\section{METODE}

Penelitian ini menggunakan analisis deskriptif dan analisis inferensia. Analisis deskriptif digunakan untuk memberikan gambaran umum mengenai keadaan rumah tangga kumuh perkotaan untuk setiap provinsi di Indonesia dengan menggunakan tabel dan grafik. Dalam analisis inferensia akan digunakan model regresi yang bisa menangkap hubungan antara jumlah rumah tangga kumuh di perkotaan dengan variabel yang memengaruhinya. Karena jumlah rumah tangga kumuh di perkotaan cukup kecil dan mempunyai kejadian yang langka maka digunakan model Regresi Poisson dan Binomial Negatif. Regresi Binomial Negatif untuk mengantispasi munculnya kejadian overdispersi pada data count ( Ismail \& Jemain, 2007). Padahal data observasi sering kali ditemukan nilai varians lebih besar daripada nilai meannya yang disebut dengan istilah overdispersi.

Model yang digunakan adalah (Hilbe, 2011) :

$$
\begin{aligned}
& Y_{i}=t_{i} e^{X_{i}^{T} \boldsymbol{\beta}}+\varepsilon_{i} \\
& t_{i}=\text { variabel exposure } \\
& E\left(Y_{i}\right)=\mu_{i}
\end{aligned}
$$

$\boldsymbol{X}_{i}^{T}=\left(X_{0 i}, X_{1 i}, X_{2 i}, \ldots, X_{7 i}\right)$

$\boldsymbol{\beta}^{T}=\left(\beta_{0}, \beta_{1}, \beta_{2}, \ldots, \beta_{7}\right)$

Dimana

$y_{i}$ : Jumlah rumah tangga kumuh perkotaan provinsi ke-i $(i=1, \ldots, 34)$

$x_{1 i}$ : Tingkat Penganggura Terbuka (TPT) perkotaan di provinsi ke-i

$x_{2 i}$ : Rata-rata Lama Sekolah (RLS) perkotaan di provinsi ke-i

$x_{3 i}$ : Persentase rumah tangga miskin perkotaan di provinsi ke-i

$x_{4 i}$ : Rata-rata anggota rumah tangga perkotaan di provinsi ke-i

$x_{5 i}$ : Persentase hunian bukan milik sendiri perkotaan di provinsi ke-i

$x_{60}$ : Tipologi wilayah barat (referensi)

$x_{61}$ : Tipologi wilayah timur

Estimasi parameter model $\left(\boldsymbol{\beta}^{T}\right)$ untuk Regresi Poisson maupun Binomial Negatif dilakukan dengan metode maximum likelihood estimation (MLE). Dimana untuk mendugakan solusi dari parameter likelihood digunakan metode numerik seperti Newton Raphson dan Fisher Scoring.

\section{HASIL DAN PEMBAHASAN}

Berdasarkan Survei Sosial Ekonomi (Susenas) tahun 2019 terdapat 3,61\% atau sejumlah 1.424.563 rumah tangga kumuh berada perkotaan di Indonesia. Adapun ciri-ciri dari rumah tangga kumuh perkotaan di Indonesia berdasarkan karakteristik Kepala Rumah Tangga (KRT) dan Anggota Rumah Tangga (ART) antara lain: 
1. Pendidikan KRT

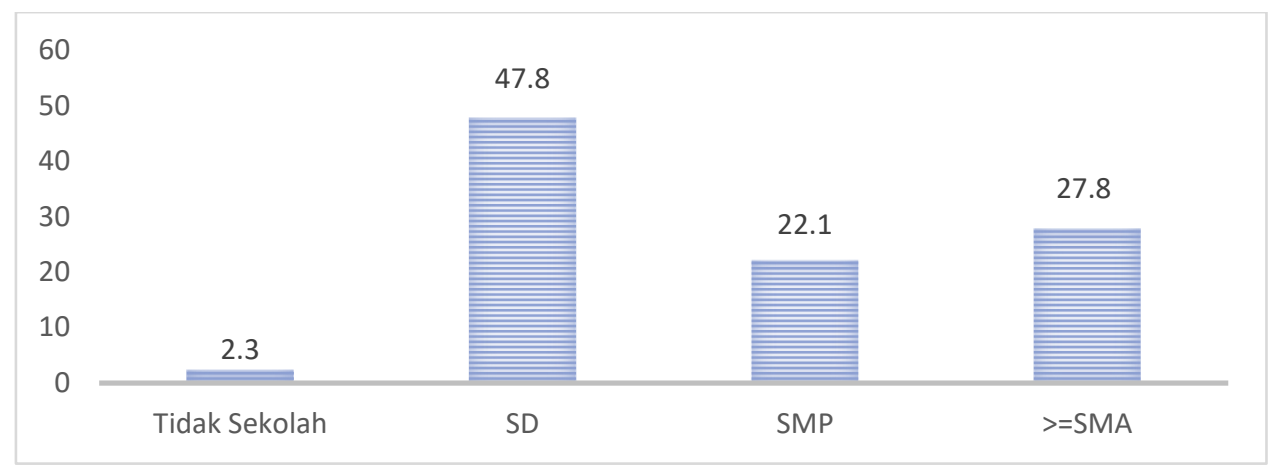

Gambar 1. Persentase rumah tangga kumuh perkotaan berdasarkan pendidikan kepala rumah tangga.

Pada gambar 1 menunjukkan bahwa mayoritas rumah tangga kumuh dikepalai oleh KRT yang berpendidikan sampai sekolah dasar. Sedangkan hanya ada 2 sampai 3 dari 100 rumah tangga kumuh perkotaan yang dikepalai oleh KRT tidak bersekolah. Selanjutnya KRT yang berpendidikan di atas sekolah dasar (SMP, >=SMA) hanya ada sebesar kurang dari 30 peren. Tingginya persentase KRT yang berpendidikan di atas sekolah dasar akibat dari banyaknya fasilitas pendidikan yang berada di daerah perkotaan. Dimana tersedianya fasilitas pendidikan tersebut menjadi salah satu indikator untuk dapat diklasifikasikan menjadi perkotaan.

\section{Jenis Kelamin KRT}

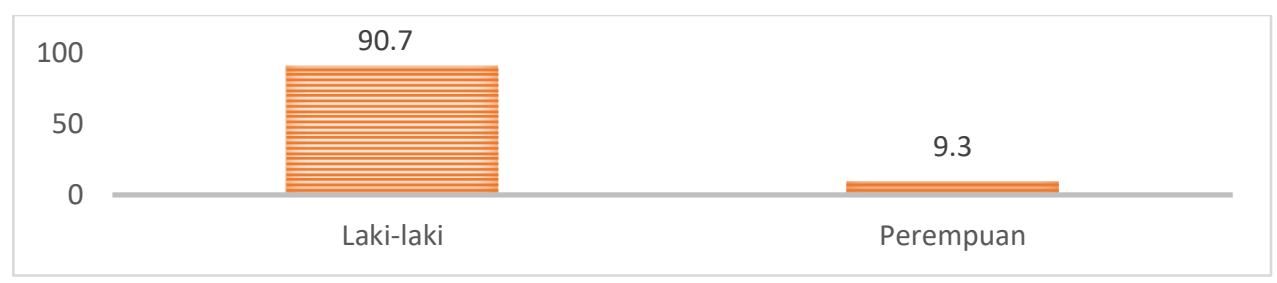

Gambar 2. Persentase rumah tangga kumuh perkotaan berdasarkan jenis kelamin kepala rumah tangga.

Berdasarkan gambar 2, jika jumlah rumah tangga kumuh dibandingkan berdasarkan jenis kelamin, persentase rumah tangga kumuh lebih didominasi oleh laki-laki sebesar 90,7 persen sedangkan perempuan sebesar 9,3 persen. Artinya bahwa kepala rumah tangga yang berjenis kelamin laki-laki lebih mendominasi daripada perempuan

3. Umur KRT

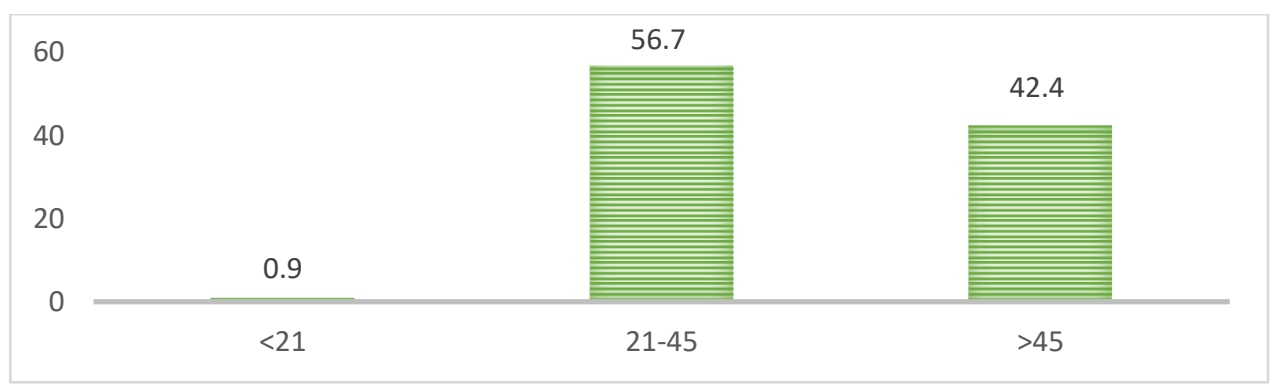

Gambar 3. Persentase rumah tangga kumuh perkotaan berdasarkan umur kepala rumah tangga.

Berdasarkan gambar 3, keberadaan rumah tangga kumuh di daerah perkotaan memiliki kaitan dengan umur dari kepala rumah tangga. Kurang dari 1 persen rumah tangga kumuh yang dikepalai oleh kelompok umur kurang dari 21 tahun. Kemudian terjadi peningkatan jumlah rumah 
tangga kumuh sebesar 56,7 persen yang dikepalai oleh kelompok umur 21-45 tahun. Persentase yang besar pada kelompok umur 21-45 masih sejalan dengan sulitnya akses untuk mendapatkan Kredit Pemilikan Rumah (KPR). Karena dengan menggunakan KPR rumah yang disediakan sudah mampu dikategorikan layak. Sedangkan jumlah rumah tangga kumuh menurun ketika dikepalai oleh kelompok umur lebih dari 45 tahun. Semakin bertambahnya usia akumulasi pendapatan yang dimiliki akan meningkat sehingga pendapatan tersebut akan mampu mengubah kondisi tempat tinggal.

\section{Jumlah Anggota Rumah Tangga}

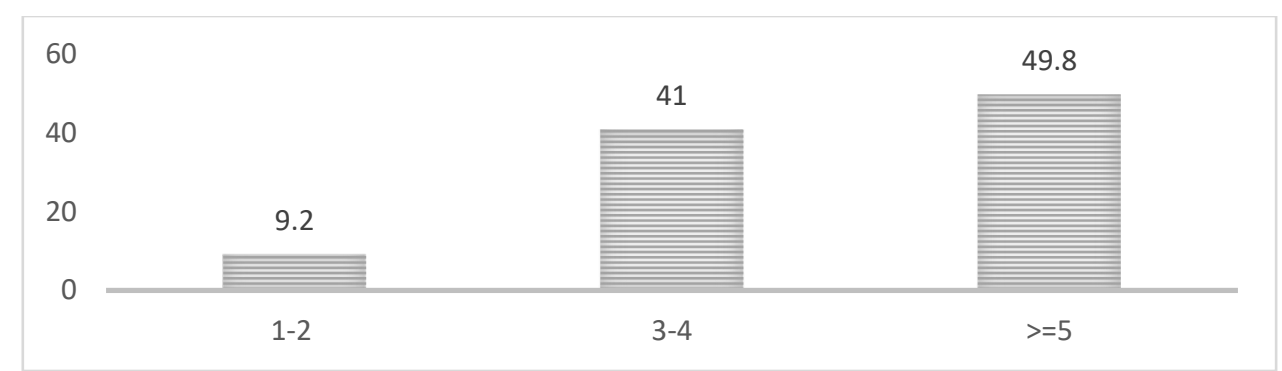

Gambar 4. Persentase rumah tangga kumuh perkotaan berdasarkan jumlah anggota rumah tangga.

Berdasarkan gambar 4, rumah tangga kumuh cenderung berasal dari rumah tangga yang berukuran besar. Oleh karena itu, semakin banyak anggota rumah tangga berarti semakin bertambah kebutuhan yang harus dipenuhi. Padahal kondisi pendapatan rumah tangga di wilayah kumuh tergolong rendah. Dampak yang terjadinya adalah sulitnya memenuhi kebutuhan pokok terutama tempat tinggal yang layak, sehingga wajar rumah tangga yang memiliki jumlah anggota rumah tangga berukuran besar lebih besar berada di rumah tangga kumuh perkotaan.

Sebelum dilakukan analisis, terlebih dahulu dilakukan pengujian yang berkaitan dengan asumsi yang digunakan yakni uji multikolinieritas. Hasil uji multikolinieritas dapat dilihat pada tabel 1. dengan menggunakan nilai Variance Inflation Factor (VIF), terlihat bahwa variabel prediktor yang digunakan tidak ada yang memiliki nilai VIF lebih dari 10 . Sehingga semua variabel prediktor dapat digunakan dalam pembentukan model.

Tabel 1. Uji Multikolinieritas

\begin{tabular}{|l|c|c|c|c|c|c|}
\hline & $\mathrm{X} 1$ & $\mathrm{X} 2$ & $\mathrm{X} 3$ & $\mathrm{X} 4$ & $\mathrm{X} 5$ & $\mathrm{X} 6$ \\
\hline VIF (Variance Inflation Factor) & 1,568 & 3,110 & 1,399 & 2,232 & 3,002 & 1,385 \\
\hline
\end{tabular}

Sumber : Output SPSS (diolah)

Hasil uji simultan dengan uji likelihood ratio dapat diperoleh bahwa Regresi Poisson dengan variabel prediktor lebih baik dari model yang hanya menggunakan Intercept pada taraf nyata 0.05 . Nilai $G_{O b s}^{2}=250.238,970$ lebih besar dari nilai $\chi_{(0,95(6))}^{2}=12,592$ atau $p$-value $<0,05$. Pengujian secara parsial untuk regresi Poisson. Selanjutnya, penelitian ini perlu melakukan pengujian overdispersi pada Regresi Poisson.

Kasus overdispersi terjadi karena nilai varian variabel respon lebih besar dari nilai rataratanya. Pengujian overdispersi dapat dilakukan menggunakan nilai pearson chi-square/derajat bebas $\left(\frac{\chi_{(\alpha)}^{2}}{d f}=1\right)$, dimana jika nilai tersebut bernilai lebih dari 1 maka terjadi overdispersi. Model regresi Poisson yang terbentuk di atas memiliki nilai pearson chi-square $\left(\chi_{(0,05)}^{2}=114.225,229\right)$ dan $\frac{\chi_{(0,05)}^{2}}{27}=4230,564>\frac{\chi_{(\alpha)}^{2}}{d f}=1$. Sehingga model regresi Poisson terjadi kasus overdispersi.Salah satu cara alternatif untuk mengatasi overdispersi dengan menggunakan Regresi Binomial Negatif.

Karena terdapat overdispersi, maka model regresi Poisson tidak cocok untuk diterapkan pada pemodelan jumlah rumah tangga kumuh perkotaan di atas. Maka dari itu dilakukan pemodelan dengan model regresi Binomial Negatif. Kemudian dilakukan pengujian secara simultan dan model regresi Binomial Negatif dengan variabel prediktor lebih baik daripada hanya 
menggunakan intercept pada taraf nyata 0,05 . Nilai $G_{O b s}^{2}$ yang diperoleh sebesar 21,509 lebih besar dari $\chi_{(0,95(6))}^{2}=12,592$ atau dan nilai $p$-value $<0,05$. Dan hasil dari model binomial negatif diperoleh sebagai berikut:

Tabel 2. Hasil estimasi parameter Regresi Binomial Negatif

\begin{tabular}{|c|c|c|c|c|c|c|}
\hline \multicolumn{2}{|l|}{ Variabel prediktor $(\mathrm{X})$} & \multirow[b]{2}{*}{ (3) } & \multirow[b]{2}{*}{ (4) } & \multirow{2}{*}{$\begin{array}{c}\text { Z Test } \\
(5)\end{array}$} & \multirow[b]{2}{*}{ (6) } & \multirow{2}{*}{$\begin{array}{c}\text { p-value } \\
(7)\end{array}$} \\
\hline (1) & (2) & & & & & \\
\hline Intercept & & $-4,104$ & 1,411 & 8,458 & 0,017 & 0,004* \\
\hline TPT & $\mathrm{X}_{1}$ & 0,144 & 0,055 & 6,905 & 1,155 & 0,009* \\
\hline Rata-rata lama sekolah & $X_{2}$ & $-0,311$ & 0,194 & 2,556 & 0,733 & 0,110 \\
\hline Persentase ruta miskin & $X_{3}$ & 0,106 & 0,031 & 11,891 & 1,112 & $0,001 *$ \\
\hline $\begin{array}{l}\text { Rata-rata ART } \\
\text { perkotaan }\end{array}$ & $\mathrm{X}_{4}$ & 0,301 & 0,369 & 0,665 & & 0,415 \\
\hline $\begin{array}{l}\text { Persentase hunian } \\
\text { bukan milik sendiri }\end{array}$ & $X_{5}$ & 0,037 & 0,015 & 5,800 & 1,038 & $0,016^{*}$ \\
\hline $\begin{array}{l}\text { Tipologi wilayah }= \\
\text { Timur } \\
\text { Tipologi wilayah = Barat } \\
\text { (referensi) }\end{array}$ & $X_{6}$ & 0,368 & 0,180 & 4,188 & 1,445 & $0,041 *$ \\
\hline
\end{tabular}

Sumber : Output SPSS (diolah)

Keterangan : *) signifikan pada taraf nyata 0.05

Dari tabel 2 diperoleh persamaan Regresi Binomial Negatif sebagai berikut :

$\log \left(\frac{\widehat{\mu}}{t}\right)=-4,104+0,144 X_{1}{ }^{*}-0,311 X_{2}+0,106 X_{3}{ }^{*}+0,301 X_{4}+0,037 X_{5}{ }^{*}+0,368 X_{6}{ }^{*}$

Hasil pengujian parsial dapat dilihat pada tabel 1 , yaitu rata-rata lama sekolah dan ratarata ART perkotaan karena nilai $p$-value lebih besar daripada nilai taraf nyatanya $(0,05)$.

Sesuai dengan persamaan 1 dapat diinterpretasikan bahwa setiap kenaikan satu persen tingkat pengangguran terbuka akan menambah tingkat rumah tangga kumuh perkotaan sebesar $(1,155-1) * 100 \%=15,5 \%$ dengan asumsi variabel lain konstan. Tingginya tingkat pengangguran disebabkan rendahnya pendidikan, kurangnya ketrampilan, dan pengalaman yang dimiliki serta tidak seimbangnya antara pekerjaan dengan lahan pekerjaan. Penyebab tersebut akan berimplikasi kepada rendahnya penghasilan yang diterima. Sehingga sangat sulit bagi mereka dengan berpenghasilan rendah untuk meningkatkan kualitas hidup terutama dalam hal hunian layak. Alhasil keadaan tersebut akan menambah jumlah rumah tangga kumuh. Dengan demikian, kondisi ketenagakerjaan sangat berkaitan dengan perkembangan daerah kumuh sesuai dengan penelitian yang dilakukan Suud dan Navitas (2015) di Kelurahan Tanah Kalikedinding.

Sementara itu, setiap kenaikan satu persen dari ruta miskin akan menambah tingkat rumah tangga kumuh perkotaan sebesar $(1,112-1) * 100 \%=11,2 \%$ dengan asumsi variabel lain konstan. Beberapa penelitian yang mendukung adanya keterkaitan antara kemiskinan dengan kekumuhan diantaranya Nursyamsiyah (2015) dan Luhar (2014). Pendapatan atau pengeluaran di bawah standar menjadi salah satu indikator untuk dapat dikategorikan sebagai penduduk miskin. Pada penelitian Izzudin dan Risyanto (2014), Malau (2006) dan Surtiani (2006), menyatakan bahwa pendapatan sangat berpengaruh signifikan terhadap timbulnya kawasan kumuh. Pendapatan atau pengeluaran yang di bawah standar akan sulit untuk mendapatkan rumah yang layak huni, sehingga menetap di kawasan kumuh menjadi salah satu alternatif untuk bertahan hidup di daerah perkotaan. 
Kemudian untuk persentase hunian bukan milik sendiri, setiap kenaikan satu persen dari hunian bukan milik sendiri akan menambah tingkat rumah tangga kumuh perkotaan sebesar $(1,038-1) * 100 \%=3,8 \%$ dengan asumsi variabel lain konstan. Sejalan dengan penelitian Surtiani (2006) bahwa kawasan kumuh sebagai akibat dari perilaku pendatang yang tidak merasa ikut memiliki dan menjaga, bahkan beranggapan hanya tinggal sementara waktu di dalam bangunan tempat tinggal mereka.

Selanjutnya pada variabel tipologi wilayah, Kawasan Timur Indonesia (KTI) akan menambah tingkat rumah tangga kumuh perkotaan sebesar $(1,445-1) * 100 \%=44,5 \%$ lebih besar daripada Kawasan Barat Indonesia (KBI) dengan asumsi variabel lain konstan. Menurut Dachlan dan Suhab (2014) bahwa dalam banyak hal, KTI identik dengan ketertinggalan, keterbelakangan, keterisolasian, dan kemiskinan. Sehingga kesejahteraan masyarakat di KTI sangat kurang akibat terbatasnya sarana dan prasarana yang memadai. Bahkan dalam hal perumahan, masyarakat KTI sangat sulit untuk bertempat tinggal di hunian yang layak. Dengan demikian jika hal tersebut dibiarkan akan menambah kawasan kumuh.

Selain itu, variabel rata-rata lama sekolah menjadi tidak signifikan setelah terjadi overdispersi pada Regresi Poisson. Hal ini dimungkinkan karena rata-rata lama sekolah di perkotaan tidak memiliki variasi yang besar antara provinsi di Indonesia, sama halnya dengan variabel rata-rata jumlah anggota rumah tangga pada umumnya seragam.

\section{KESIMPULAN}

Berdasarkan hasil dan pembahasan sebelumnya, penelitian ini dapat disimbulkan beberapa hal antara lain:

1. Persentase rumah tangga kumuh perkotaandi Indonesia (Maret 2019) adalah sebesar 3,61 persen. Lima provinsi yang menjadi perhatian khusus, dengan nilai persentase rumah tangga kumuh perkotaan tertinggi yakni Sumatera Selatan, Nusa Tenggara Timur, Maluku, Papua, dan Papua Barat. Rumah tangga kumuh perkotaan dicirikan oleh pendidikan KRT yang rendah (SD ke bawah) sebesar 47,8 persen, jenis kelamin KRT 90,7 persen adalah laki-laki, usia KRT yang cukup muda antara 21 hingga 45 tahun (usia produktif) sebesar 56,7 persen, dan jumlah ART lebih dari 4 orang sebesar 49,8 persen.

2. Model yang tepat untuk menjelaskan data rumah tangga kumuh di daerah Indonesia adalah regresi binomial negatif. Berdasarkan hasil analisis didapatkan variabel prediktor yang memengaruhi tingkat rumah tangga kumuh yaitu: tingkat pengangguran terbuka, persentase rumah tangga miskin, persentase hunian bukan milik sendiri dan tipologi wilayah. Sedangkan variabel rata-rata lama sekolah dan rata-rata jumlah anggota rumah tangga tidak signifikan memengaruhi tingkat rumah tangga kumuh

3. Berdasarkan hasil dari model regresi binomial negatif tingkat pengangguran terbuka, persentase rumah tangga miskin, persentase hunian bukan milik sendiri dan tipologi wilayah memiliki hubungan positif terhadap tingkat rumah tangga kumuh perkotaan.

\section{DAFTAR PUSTAKA}

Ahmad, S., Choi, M. J., \& Ko, J. (2013). Quantitative and Qualitative Demand for Slum and Non-Slum Housing in Delhi: Empirical Evidences from Household Data . Elsevier, 90-99.

Badan Pusat Statistik. (2019). Kajian Lingkungan Hidup : Kualitas Lingkungan Hidup Perkotaan. Jakarta: BPS.

Dachlan, D., \& dkk. (2014). Pembangunan Kawasan Timur Indonesia Dalam Konteks Kekinian Indonesia. Makassar: P3KM Unhas Press.

Fitria, N., \& Setiawan, R. (2014). Identifikasi Karakteristik Lingkungan Permukiman Kumuh di Kelurahan Kapuk, Jakarta Barat. Jurnal Teknik POMITS Vol 3, No. 2, 240-244.

http://ejurnal.its.ac.id/index.php/teknik/article/view/7290

Hilbe, J. M. (2011). Negative Binomial Regression Secon Edition. United States of America: Cambridge University Press.

Ismail, N., \& Jemain, A. A. (2007). Handling Overdispersion with Negative Binomial and Generalized Poisson Regression Model. Casualty Actuarial Society Forum, 103-158.

https://www.casact.org/pubs/forum/07wforum/07w109.pdf 
Izzudin, M., \& Risyanto . (2014). Pengaruh Sosial Ekonomi Penghuni Terhadap Permukiman Kumuh di Kecamatan Wonokromo Kota Surabaya. Jurnal Bumi Indonesia, 1-8. http://lib.geo.ugm.ac.id/ojs/index.php/jbi/article/view/619

Luhar, H. (2014). Causes for the Creation and Expansion of Slum. Sai Om Journal of Commerce \& Management Volume I, Issue 10, 56-58.

Mberu, B. U. (2005). Internal Migration and Household Living Conditions in Ethiopia. APHRC Working Paper, $1-24$.

https://www.researchgate.net/publication/4746574 Internal migration and household living condi tions in Ethiopia/link/54c4fc4a0cf219bbe4f17349/download

Nursyamsiyah, S. (2015). Faktor-Faktor yang Menyebabkan Permukiman Kumuh di Kota Bandar Lampung [Tesis]. Lampung: Universitas Lampung.

Rindarjono, M. G. (2017). Kajian Permukiman Kumuh dalam Perspektif Spasial. Yogyakarta: Media Perkasa.

Suparlan, P. (2004). Masyarakat \& Kebudayaan Perkotaan Perspektif Antropologi Perkotaan. Jakarta: Yayasan Pengembangan Kajian Ilmu Kepolisian.

Surtiani, E. E. (2006). Faktor-Faktor yang Mempengaruhi Terciptanya Kawasan Permukiman Kumuh di Kawasan Pusat Kota (Studi Kasus: Kawasan Pancuran, Salatiga) [Tesis]. Semarang: Universitas Diponegoro.

Suud, B., \& Navitas, P. (2015). Faktor-faktor Penyebab Kekumuhan Permukiman di Kelurahan Tanah Kalikedinding, Kecamatan Kenjeran, Surabaya. Jurnal Teknik ITS Vol. 4 No. 1, 33-35. http://ejurnal.its.ac.id/index.php/teknik/article/view/8994

Tanni, T., Hasan, M., Azad, A., \& Bakali, B. (2014). State of the Environment in Slum Area: A Case Study on Khora Slum, Khulna. J. Environ. Sci. \& Natural Resources, 295-304. https://www.banglajol.info/index.php/JESNR/article/view/22187

UN-Habitat. (2006). The State of The World's Cities Report 2006/2007. United State of America: Earthscan.

Wardhana, N. H., \& Sulistyarso, H. (2015). Faktor-Faktor Penyebab Kekumuhan Di Kelurahan Kapasari Kecamatan Genteng, Kota Surabaya. Jurnal Teknik ITS, 150-154. http://ejurnal.its.ac.id/index.php/teknik/article/view/11013

World Bank. (2015). East Asia's Changing Urban Landscape. Washington DC: World Bank.

World Bank. (2019). Time to ACT Realizing Indonesia's Urban Potential. Washington DC: World Bank.

Zulkarnaini, W. R., Elfindri , \& Sari, D. T. (2019). Faktor-Faktor yang Mempengaruhi Permukiman Kumuh di Kota Bukittinggi. Jurnal Planologi, 169-188.

http://jurnal.unissula.ac.id/index.php/psa/article/view/5047 